\title{
TRANSFER OF INTEGRAL PSYCHOLOGY AND PEDAGOGY INSIGHTS INTO HIGH SCHOOL STUDY PROCESS
}

\author{
Regina Baltusite, Irena Katane \\ Latvia University of Life Sciences and Technologies, Latvia \\ rilagora@inbox.lv, irena.katane@1lu.lv
}

\begin{abstract}
Latest researches and new branches of science not only influence their own development, they also affect the development of other fields. Globally, everything is mutually connected. Changes in one branch of science influence the other branches of science. The same can be also related to the integral psychology and pedagogy. In our contemporary unusual world, it is important to perceive things and events in aggregate. This is exactly that creates the essence of integrity. To understand the complexity of the surrounding world, it is important to learn expanding beyond the limits of your personality, beyond your usual activities and methods. The insights of the integral theory were represented by the American scientist K.Wilber. The integral psychology is the psychology of the totality. The internal pedagogy is the holistic pedagogy, a way of developing the pedagogical thinking, viewing a person as a unity of the spirit, soul and body. The aim of the article is to analyse the theoretical insights related to the introduction of the integral theory to psychology and pedagogy and to consider its transfer into the study process in high schools. To achieve the goal set by the article, the following research methods were used. The theoretical justification of the article is based on the analysis and synthesis of bibliography sources. Reflection of personal experience of the authors of the article plays an important role in the creation of the article (the authors of the article are delivering their study courses on various education levels for students of various speciality fields and ages). The transfer of the insights of the integral psychology and pedagogy into the study process of high schools, including the engineering high schools, will promote the holistic way of looking at things and events, creativity, development of personal capacities, the possibility to personalize the education (creation of personalized educational programmes), improvement of mutual relations. The AQAL model elaborated by K.Wilber can be used for the evaluation and planning of a person's life journey. The AQAL model can be used for solving of various problems, it can be also learned by students. The article provides justification for the inclusion of the insights of the integral psychology and pedagogy in the higher education study process.
\end{abstract}

Keywords: engineer education, integral theory, integral psychology, integral pedagogy.

\section{Introduction}

Nowadays the engineering science is one of the fields which will be highly demanded, and it will continue its development. Therefore, the methods that would promote the sustainability of the profession should be included in a higher school study process as such and in the engineering studies in particular. The term "engineer" arose in the second century AD. Translated from Latin, it means "devious, witty, and ingenious" [1]. The essence of the engineer's activity is the application of the system of scientific knowledge in his practical activity. An engineer is a scientist and a practitioner at the same time. A technical higher school graduate is a specialist who has knowledge and skills necessary for the execution of an engineer's functions, but who has also good communicative skills, foreign language knowledge [1;2]. Therefore, the interdisciplinary approach plays an important role during the study process. The interdisciplinary approach has been considered by scientists from various states in their works and projects (education ecology - Katane, interdisciplinarity in higher education institutions Senashenko, 2017; Spelt e.a., 2009; holistic approach in lifelong education - Lifelong Learning Platform and Cedefop, 2019; promotion of entrepreneurial competencies - Oganisjana, 2015) [3-6]. We are living in the world of rapid changes. The approach to education and its content is changing accordingly. The contemporary integration theory started developing in the 40 s of the $20^{\text {th }}$ century. The term "integral" has been used and is still used in the works of I. Sen, H. Chaudhuri, V. Merlin, K. Wilber and others [7-9]. "Integral" means "inseparably linked, whole, unified". The term "integration" in its turn means renovation, merging of some parts into one whole, as well as the process of merging the parts themselves. The term is not a new one and it is connected with the holistic approach. The insights of the holistic approach can be found in Ancient Greece (Thales, Heraclitus) [7]. The most frequent use of the term marks a strong tendency for the understanding of things and phenomena in the aggregate, when the existing situation does not allow for getting questions answered based on obsolete knowledge, because the world appears to be more diversified. The most prominent representative of the contemporary integral theories is an American scientist K. Wilber, whose integral theory is formed by the fusion of Science, Psychology, Philosophy and Spirituality $[10 ; 11]$. The term "integral" is gradually entering 
various fields of science. Pedagogy and psychology have also developed the fields of integral pedagogy and psychology. The integral psychology (or the psychology of the entirety) is a general approach to psychology trying to combine various psychology theories by including the discoveries of other fields. The integral psychology is developing within the multidisciplinary research (developmental psychology, deep psychology, transpersonal psychology, cognitive sciences, mysticism of the East and West). During the recent years, the integral psychology has started to develop into the academic science (conferences, research - promotion theses, articles etc.). The subject-matter of the integral pedagogy is the integrity of a human and the world [12]. Both in the integral psychology and pedagogy, a great importance is attached to the Spirit and the characteristic features of the Spirit, which contributes to overcoming duality and better understanding of the surrounding world and the reasons of processes going on in this world.

The aim of the article is to analyse the theoretical insights related to the introduction of the integral theory to psychology and pedagogy and to consider its transfer into the study process in high schools.

\section{Materials and methods}

In order to achieve the goal set in the article, the following research methods have been used. The theoretical justification of the article is based on the analysis and synthesis of the bibliography sources. The reflection of personal experience of the authors of the article plays an important role in the process of compilation of the article (the authors of the article deliver their study courses on various education levels and for the students of various specializations and of various age). K.Wilber's integral model (AQAL) was used as a career planning method. The AQAL model elaborated by the author can be not only used in theory, but also in practice. The model is based on the embedded possibilities of unlocking personal potential [9].

The model includes: a) four quadrants - various types of existence theory (I, It, Its, We); b) the levels of development of the consciousness depicted as growing from one level to another (in spiral order); c) development lines - various abilities of a human (cognitive, emotional, moral, intrapersonal, aesthetic etc.); d) states of consciousness - possibilities of spiritual experience (crude, subtle, causal and non-dual); e) types - sex, representatives of each sex must go through the three stages of moral development in different ways [10]. Using the AQAL model, we can define our consciousness level and understand our limits, as Socrates used to say [10]. In its turn, it contributes to your engagement with your strong points and those that need to be developed, as well as with the strong and weak points of other people. Based on the model, a program can be created for a person where he can clearly see the present situation and pay his attention to personal improvement. The model gives a wider possibility to examine the integral profile of a personality. Therefore, the model should be used in both career support and life purpose implementation. The model is useful for the assessment of a person's situation, emotions or experience.

\section{Results and discussion}

Engineer is a multidisciplinary profession. Participating in various projects, the engineer's job can be connected with the specialists from various spheres, such as business, psychology, health etc. An engineer must be also able to communicate his thoughts and ideas to non-technicians $[1 ; 2 ; 14-16]$. The demands set up for the engineers-to-be, which can be also related to working engineers, are as follows [13-16]: a) to adapt to changing working conditions and to learn changing them in accordance with time and situation; b) to implement his professional qualities within his professional activity in the best possible manner (ideas, projects, technical audits, application and maintenance of complex technologies); c) to form and control mutual relations with other people within mutual activities (teamwork, responsibility for certain decisions, mutual understanding, cooperation, participation in the professional communication - sharing of information, innovative ideas, work experience with the colleagues; accurate expression of his thoughts, providing of basis for his opinion); d) competence to work in international environments; e) understanding other cultures. PSMJ Resources interviewed its work departments about the skills required for their engineers to ensure good work. As a result, the main skills mentioned where "follows through on commitments, good listener, proactive, nails every aspect of the job, leads by example, good communicator, backs decisions of team members, organized, handles 
multiple priorities well, technically proficient, holds people accountable, delegates well". The importance of communicative skills is underlined here as well [15].

The main problem in the development of the future engineers is a sustainability of the engineering education. Researchers conclude that various methods, including the cooperative problem-based learning, must be used also in the engineering study courses, as it stimulates the relationships, attitudes, change of the study environment, cultural and ethical values, sustainable behavior, integral education as transformational leadership, which affects the personal development of students, their professional life, and community [17]. The authors underline that it must be done already during the first-year studies. Another thing offered by the scientists for the engineering studies is a project-based learning related to the field, when the students are offered to solve simple real-life manufacturing problems already during the first year of studies, which the students try to solve independently under the supervision of their teachers and attracting also the representatives of enterprises. This way they broaden their professional experience, develop a creative approach to problem solving and get gradually engaged in working environment. The research carried out in 10 biggest energy enterprises in the Vaasa region in Ostrobothnia, Finland, established that energy enterprises are looking for specialists having technical experience. It is desirable for the specialists to have technical and economical competencies, basic knowledge in electricity, IT, English and international communication. It attests that future specialists must be skillful in various aspects of professional activity [18]. It can be implemented during the interdisciplinary studies only.

Interdisciplinarity in education has been discussed for many years, yet its implementation is carried out gradually, and disciplinary education still remains the basic approach. It is essential so that interdisciplinarity is a part of study programs. It is also provided by the competence approach in education, as the goal of the interdisciplinary education corresponds to the goal of the university - a student develops during the studies both as a cultural person and as a professional of his field $[3 ; 4]$.

Benefits of the university in result of the implementation of the interdisciplinary approach during the study process: 1) new inter-institutional and inter-faculty study programs; 2) new forms of organization of studies; 3 ) formation of an interdisciplinary study environment within the university; 4) development of creative ability of the students; 5) graduates with high professional competences; 6) tighter cooperation with employers [3].

Implementing the interdisciplinary approach, attention must be paid to the following aspects: 1) on which level is it implemented? (according to difficulty level or according to interaction level within various education structures); 2) it must include culturological and professional competences; 3) teachers must be prepared for the work in the interdisciplinary teams; 4) new forms of academic work organization must be introduced; 5) changes will take place in the internal structure of the university in accordance with the interdisciplinary study process [3].

Implementation of interdisciplinarity in the study process is essential, yet it is mainly based on the external aspects of science, which not always consider a so-called "mystical experience" of a person. The term integral psychology was used for the first time in 1940s by I. Sen - a student of Indian mystic Sri Aurobindo [8]. Sri Aurobindo attached a great importance to education, so that young people would be ready to live in a unified world. Whereas the basics of the integral psychology can be found in the works of H. Chaudhuri of the 1970s. The author expresses the opinion that the integral psychology is based on the three principles - uniqueness, mutual connection and transcendence, which is connected with various levels of human experience - personal, intrapersonal and subpersonal [9]. In general, the integral psychology is developing within the transpersonal psychology occurred in the $60 \mathrm{~s}$ of the $20^{\text {th }}$ century. The leading role in modern integral psychology belongs to K. Wilber. The most prominent representative of the contemporary integral theories is the American scientist K. Wilber, whose integral theory is formed by the fusion of Science, Psychology, Philosophy and Spirituality [9].

It is important on any level of education to teach the life purpose, as a new generation studying in a higher school is looking for the answer to the question: "What for?" [19]. This is a question of the life purpose. The study courses should promote the implementation of the life purpose accordingly. All the study courses are doing it, but the integral whole is still missing. Both teachers and students must have a holistic approach to life. Everyone comes to this world with their own mission. Therefore, it is important to teach people for life, as everything is important in life - satisfaction of various levels of 
their needs, work, leisure, creativity, entertainment, education and upbringing. We can agree with the author's opinion, who believes that from the point of view of the integral pedagogy the equality can be stated between the life purpose and the education purpose [10;12]. A holistic integral pedagogy is a spiritual essence of education and a spiritual teacher, who understands his own integrity (Figure 1).

\begin{tabular}{|c|c|c|}
\hline $\begin{array}{c}\text { Thinking } \\
\text { Truth }\end{array}$ & $\begin{array}{c}\text { Feelings } \\
\text { Moral and Beauty }\end{array}$ & $\begin{array}{c}\text { Will } \\
\text { Goodness }\end{array}$ \\
\hline \multicolumn{2}{|c|}{ LOVE } \\
\hline
\end{tabular}

Fig. 1 Characteristic features of Spirit

The study process includes the relationships between a teacher and a student, forming a pedagogical relation. Based on the analysis of the theoretical insights, D.\&L. Šatohins indicates the role of the integral pedagogy in the study process at a higher school - forming of conditions for the development of creative abilities of a student in the student-teacher relation system [7]. The integral pedagogy emphasizes: diversified and timely development of youngsters; forming the skills of personal self-education and self-fulfilment; forming the holistic understanding of the world and scientific view of life; improvement of the curriculum content based on the integration of spiritual and moral aspects, etc. $[10 ; 12]$.

According to the authors' opinion, which is based on the reflection of their personal experience, some modules can be offered to students, where 2-3 teachers are reading lectures at the same time (in tandem rather than each of them reading his own part of the course separately). It will contribute to better understanding and implementation of the study material, broader possibilities of practical activity, and versatile methods can be used in mastering of the study material. A student within this process is active and he is cooperating with the teachers. This way, a mutual exchange of energy, knowledge, experience happens and a broader view on things and phenomena is acquired. A good multidisciplinary practice is the creation of new multidisciplinary programs by the cooperation of several faculties, but with the view towards the future, including spiritual values and understanding of the Spirit into the curriculum, as well as the role of the development of personality, which affects the manifestation of a person's creativity. The implementation of the insights of the integral pedagogy and psychology is an important aspect in understanding of a university as a one whole by its employees and students, evaluating it through the AQAL model for the four quadrants, as according to K. Wilber, a truly integral education does not impose the green meme upon everybody, it rather perceives it as a gradual transfer from magical to mystical, then to reasonable and integral wave, underlying all waves in the process of passing.

The integral theory of $\mathrm{K}$. Wilber is reflected in his AQAL model [20]. To ensure a robust development of a human, the conscious and the unconscious mind (individual and collective) must be integrated. Collective unconsciousness is a basis of personality and it includes the development potential. AQAL by K. Wilber includes all the quadrants, all the levels, lines, all the states and all the types within the five categories, where the Universe and all the existing things are spread. This is K. Wilber's integral viewpoint on the Reality $[9 ; 20]$. The model has four quadrants (I (self and consciousness), We (culture and worldview), It (brain and organism), Its (social system and environment)), with which every individual has a contact, and which are related to the main dimensions of the Cosmos (internal and external aspect of each individual). During a year, a gap between the unity of I, We and It appears. In the course of time, the science and technology started to dominate over I and We, the consciousness and the moral [20].

The main idea of the integral transformative process is related to the involvement of a number of aspects, which will result in greater changes. The transformative process will happen more rapidly if we involve all the quadrants and all the levels. "All levels" include the waves of "being" from the substance to the body and from the brain to the soul and spirit, which is based on the Graves' spiral dynamics. In its turn, "all quadrants" are the dimensions I, We and It. Therefore, it is important to keep it in mind when planning a career (Table 1). 
Quadrants for career planning

\begin{tabular}{|l|l|l|l|}
\hline \multicolumn{2}{|c|}{ Interior } & \multicolumn{2}{|c|}{ Exterior } \\
\hline Individual & $\begin{array}{l}\text { Self and Consciousness } \\
\text { "I" subjective reality (belonging to } \\
\text { a person) consciousness states, } \\
\text { purpose, values, knowledge, } \\
\text { purpose, worldview, emotion and } \\
\text { feelings }\end{array}$ & $\begin{array}{l}\text { Behaviour and nature } \\
\text { "It" objective reality, biology, } \\
\text { neurobiology, goals, the facts, } \\
\text { habits, skills, communication, } \\
\text { health }\end{array}$ & \\
\hline Collective & $\begin{array}{l}\text { Culture and Morality } \\
\text { "We" intersubjectivity, common } \\
\text { values, corporate culture, social } \\
\text { norms, cultural and } \\
\text { communicational patterns, cultural } \\
\text { practices and customs, languages }\end{array}$ & $\begin{array}{l}\text { System } \\
\text { "Its" interobjectivity, economics } \\
\text { and environment, systems and } \\
\text { chaos theories, deep ecology, } \\
\text { structure, political order, } \\
\text { technology, resources }\end{array}$ & Collective \\
\cline { 2 - 3 } & Exterior & \\
\hline
\end{tabular}

The career planning includes self-examination, choice of profession, choice of educational institution and job search. Every component must go through all quadrants in order to harmonize all the dimensions. Then it is assessed, what could be done on physical, emotional, intellectual and spiritual basic waves of the individual's self, culture and nature. In planning, the most optimal thing shall be taken into account that an individual can do at a certain moment of time. Certain things are recorded. Based on the development lines of the model, about 20 types of abilities can be described, using the methods of definition of every development line. And having arrived to types, it gives a great opportunity to consider whether there are men and women professions that characterise the androgen personality. The benefit of the model is that all the evaluated elements are here and now, that is, they are conscious. The model gives a possibility to systemize the research toolbar in accordance with the quadrants, levels, development lines and types. It promotes the client's overall view on his career, considering all the four quadrants.

Therefore, the implementation of the holistic approach during the study process based on the insights of the integral psychology and pedagogy promotes: ) understanding of both teacher and student about the unity of the body, mind and spirit; 2) improves the mental health of students and teachers; 3) creative abilities of the students and the expression of such abilities at a superpersonal level; 4) supplementation of curriculum, which contributes to the expansion of cognition of both students and teachers, including also the spiritual aspect; 5) equal cooperation of students and teachers while implementing the curriculum of the study courses; 6) an individualised composition of the study programs using the AQAL model.

\section{Conclusions}

1. The integral theory is the basis for broadening of consciousness of a teacher and a student, forming a unified view of yourself and the world. The insights of the integral theory should be included in all study courses in order to promote the holistic approach to things and phenomena, using the AQAL model.

2. Implementation of the insights of the integral psychology and pedagogy in the study process of higher schools, including the field of engineering studies, allows for optimising the study process by increasing the volume of practical studies; as a result of cooperation of teachers (a number of teachers are working simultaneously in the related study courses) a holistic view of the study process is created. Future considerations allow for thinking about the inclusion of the basic study courses in the professional study courses. For example, the insights of philosophy, integral pedagogy and psychology can be integrated into the study courses of physics and mathematics. The contribution of teachers is a very important aspect in this process.

3. Inclusion of the insights of integral pedagogy and psychology in the study process will provide more possibilities for intense activities of the students. 
4. Based on the AQAL model, the insights of integral theory can be elaborated for the support of students' career development.

\section{References}

[1] Седов Е.И. Инженер как субъект творческой деятельности (Engineer as a Subject of Creative Activity). Субъект профессиональной деятельности: стратегии развития и риски (Subject of Professional Activity: Development Strategies and Risks'). Материалы конференции. Ростов н/Д: издательский центр ДГТУ, 2015. [online] [11.03.2019]. Available at: http://ntb.donstu.ru/files/Jubilejnyj_sbornik/conf_psih_ppl15092015.pdf (In Russian)

[2] Попов А.Н. Особенности формирования профессионально - коммуникативной компетентности будущего инженера (The features of forming a professional communicative competence of an engineer - to - be). Современные проблемы науки и образования (Current issues of science and education). 2016, № 6, [online] [11.01.2021]. Available at: http://www.science-education.ru/ru/article/view?id = 25837 (In Russian)

[3] В. С. Сенашенко. Междисциплинарность

образования как отражение многообразия окружающего мира (Interdisciplinary Education as a Reflection of the Diversity of the Surrounding World). Междисциплинарность в обучении и исследованиях. Университетское управление: практика и анализ Том 21, № 1, 2017, 88 -95, DOI 10.15826/umpa.2017.01.008 (In Russian) [online] [28.04.2021]. Available at: https://cyberleninka.ru/article/n/mezhdistsiplinarnost-obrazovaniya-kak-otrazheniemnogoobraziya-okruzhayuschego-mira

[4] Spelt E., Biemans H., Tobi H. Luning P., Mulde M. Teaching and Learning in Interdisciplinary Higher Education: A Systematic Review, 2009, DOI 10.1007/s10648-009-9113-z. Available at: https://www.researchgate.net/publication/226190834_Teaching_and_Learning_in_Interdisciplinar y_Higher_Education_A_Systematic_Review

[5] Lifelong Learning\&Cedefop. Implementing a holistic approach to lifelong learning: Community Lifelong Learning Centres as a gateway to multidisciplinary support teams, 2019, 16 p. [online] [28.03.2021]. Available at: https://www.cedefop.europa.eu/en/publications-andresources/publications/2226

[6] Oganisjana K. Starpdisciplinārās mācības uzņēmības un uzņēmējspējas veicināšanai (Interdisciplinary Teaching and Learning for Promoting Entrepreneurship). Rīga, 2015, 206 lpp. (In Latvian)

[7] Шатохин Д.Д., Шатохина Л.В. Понятие интегральности в педагогической науке. Педагогические науки, N 54-1, 2016. (In Russian). [online] [10.02.2021]. Available at: https://novainfo.ru/article/8459

[8] Sen I. Integral Psychology: The Psychological System of Sri Aurobindo. Pondicherry, India: Sri Aurobindo Ashram Trust, 1986.

[9] Chaudhuri H. The Evolution of Integral Consciousness. Wheaton, Illinois: Quest Books, 1989.

[10] Vilbers K. Visaptverošā teorija (A Theory of Everything). Rīga, Jumava, 2010. 229 p. (In Latvian)

[11] Vilbers K. Aci pret aci (Eye to Eye). Rīga, Jumava, 2013. 323 p. (In Latvian)

[12] О значении образования (On the Meaning of Education) (б.г.). (In Russian). [online] [17.01.2021]. Available at: http://ros-idea.ru/site/222

[13] OECD Future of Education and Skills 2030. OECD Learning Compass 2030. A Series of Concept Notes. 2019. [online] [17.03.2021]. Available at: https://www.oecd.org/education/2030project/contact/OECD_Learning_Compass_2030_Concept_Note_Series.pdf

[14]Бондаренко Т.A., Лесняк О.В. Проблема подготовки современного инженера системотехника (The Problem of Professional Training of Modern System - Engineer). Субъект профессиональной деятельности: стратегии развития и риски (Subject of Professional Activity: Development Strategies and Risks'). Материалы конференции. Ростов н/Д: издательский центр ДГТУ, 2015. [online] [11.03.2021]. Available at: http://ntb.donstu.ru/files/Jubilejnyj_sbornik/conf_psih_ppl15092015.pdf (In Russian)

[15] Stephens L. Why effective communication is important for 21st century engineers, 2015. [online] [10.03.2021]. Available at: https://news.engineering.utoronto.ca/why-effective-communication-isimportant-for-21st-century-engineers/ 
[16] Tsepilova A.V., Mikhaleva L.V. Integrated Development of Future Engineers' Professional and Communicative Competence. Language and Culture, 2014, p. 137 - 146 [online] [10.12.2020]. Available at: https://cyberleninka.ru/article/v/integrated-development-of-future-engineersprofessional-and-communicative-competence

[17] De la Riva G.A., de la Riva C.C., Fajardo E., Nájera M.J. Sustainability in engineering education: an approach to reach significant learning and character skills. Sustainability in Higher Education, p. $97-125$, 2015, doi.org/10.1016/B978-0-08-100367-1.00005-6. [online] [28.03.2021]. Available at: https://www.sciencedirect.com/science/article/pii/B9780081003671000056

[18] Backa L., Wihersaari M. Future Engineering Education: What Competences are Energy Companies Looking, for when Recruiting Graduates with a Master of Science (Technology) Degree? Journal of the Higher Education Academy Volume 9, 2014, p. 2-17. https://doi.org/10.11120/ened.2014.00022 [online] [28.03.2021]. Available at: https://www.tandfonline.com/toc/rhep17/current

[19] Amour M. S. Report: Gen Z Open to Nontraditional Education, 2020. [online] [27.03.2021]. Available at: https://www.insidehighered.com/quicktakes/2020/06/25/report-gen-z-opennontraditional-education

[20] Клинецкая Н.В. Интегральный подход в социокультурной парадигме Кена Уилбера (Integral approach in socioculture paradigm Kena Wilbera). Социология культуры: опыт и новые парадигмы, Труды Санкт-Петербургского государственного института культуры и искусств, Том 206 c.79 -86, 2015. (In Russian) [online] [28.03.2021]. Available at: https://cyberleninka.ru/article/n/integralnyy-podhod-v-sotsiokulturnoy-paradigme-kena-uilbera 